\title{
PENGEMBANGAN INFRASTRUKTUR JALAN SEBAGAI IMPLEMENTASI RENCANA TATA RUANG WILAYAH KABUPATEN KETAPANG
}

\author{
Ferry Juniardi ${ }^{1}$; Heri Azwansyah ${ }^{2}$ \\ ${ }^{1}$ Staf Pengajar Program Studi Teknik Sipil, Universitas Tanjungpura, Indonesia \\ ${ }^{2}$ Staf Pengajar Program Studi Teknik Sipil, Universitas Tanjungpura, Indonesia \\ Email : ferryjuniardi@gmail.com
}

\begin{abstract}
ABSTRAK
Kabupaten Ketapang merupakan kabupaten yang sedang berkembang perlu didukung dengan infrstruktur jaringan jalan yang baik. Studi ini bertujuan mengembangkan infrastruktur jaringan jalan untuk mendukung pergerakan kendaraan di Kabupaten Ketapang. Studi ini membutuhkan data-data pergerakan kendaraan dan jaringan jalan yang diperoleh dari instansi terkait dan survei lapangan. Model bangkitan pergerakan kendaraan dipengaruhi oleh jumlah sarana kesehatan (X3), sedangkan model tarikan pergerakaan kendaraan dipengaruhi oleh jumlah penduduk (X1) dan jumlah sarana kesehatan $(\mathrm{X} 3)$. Jaringan jalan arteri primer yang dikembangkan meliputi : ruas Jalan batas Kabupaten Sanggau - Batas Kecamatan Balai Berkuak; ruas Jalan Batas Kecamatan Balai Berkuak - Aur Kuning; ruas Jalan Aur Kuning - Sandai; ruas Jalan Sandai - Nanga Tayap; dan ruas Jalan Nanga Tayap - Batas Provinsi Kalimantan Tengah. Sementara itu, untuk meningkatkan aksesibilitas juga dilakukan peningkatan dan pengembangan terhadap beberapa jalan kolektor primer.
\end{abstract}

Kata kunci: model bangkitan, model tarikan, jalan primer

\begin{abstract}
Ketapang regency is growing and need to be supported by a good road network infrastructure. This study aims to develop a network infrastructure to support the movement of vehicles in Ketapang regency. This study requires data of movement of vehicles and the road network, obtained from the relevant agencies/departments and field survey. Vehicles trip generation models influenced by number of health facilities (X3), while pull models of vehicle movement influenced by number of residents (X1) and number of health facilities (X3). Primary artery roads network that was developed include: regency's boundary road of Sanggau - district's boundary road of Balai Bekuak; district's boundary road of Balai Bekuak - Aur Kuning; road segment of Aur Kuning - Sandai; road segment of Sandai - Nanga Tayap, and road segment of Nang Tayap - province's boundary of Central Kalimantan. In addition, to improve accessibility, it also necessary to makes some improvement and development of the primary collector roads.
\end{abstract}

Keywords: generation models, pull models, primary roads

\section{Pendahuluan}

Kabupaten Ketapang merupakan salah satu kabupaten di Kalimantan Barat yang merupakan kabupaten yang masih dalam tahap berkembang. Kabupaten ini berbatasan dengan Kabupaten Sangau, Kabupaten Kayong Utara, laut Jawa, laut Natuna, serta juga berbatasan dengan Propinsi Kalimantan Tengah. Wilayah ini memiliki sektor strategis yaitu sektor perkebunan, industri (agroindustri) dan pertambangan (BPS Kalbar, 2013).

Tamin (2008:38) menjelaskan bahwa pertumbuhan ekonomi menyebabkan mobilitas seseorang meningkat sehingga kebutuhan pergerakan meningkat. Hal ini menuntuk penyediaan jasa transportasi yang efisien, handal, berkualitas, aman, lancar secara intermoda dan terpadu dengan pembangunan wilayah dan dapat menjadi bagian dari suatu sistem distribusi yang mampu memberikan pelayanan dan manfaat bagi masyarakat luas, termasuk meningkatkan jaringan desa-kota yang memadai.

Dalam pembangunan rangka ekonomi mendukung dan 
Juniardi dan Azwansyah. "Pengembangan infrastruktur jalan di Kabupaten Ketapang"

pengembangan wilayah khususnya di Kabupaten Ketapang, maka harus dikembangkan infrastruktur jaringan jalan sebagai bagian dari pengembangan lalu lintas dan angkutan jalan sebagaimana dijelaskan pada Undang-Undang Lalu Lintas dan Angkutan Jalan No. 22 Tahun 2009 bahwa perkembangan lingkungan strategis nasional dan internasional menuntut penyelenggaraan Lalu Lintas dan Angkutan Jalan yang sesuai dengan perkembangan ilmu pengetahuan dan teknologi, otonomi daerah, serta akuntabilitas penyelenggaraan negara.

Langkah yang ditempuh dalam rangka mewujudkan penyelenggaraan lalu lintas dan angkutan jalan yang terpadu harus dilakukan pengembangan infrastrutkur jaringan jalan untuk menghubungkan semua wilayah daratan yang selanjutnya disusun dalam Studi Pengembangan Infrastruktur Jaringan Jalan yang merupakan serangkaian simpul dan/atau ruang kegiatan yang saling terhubungkan untuk penyelenggaraan Lalu Lintas dan Angkutan Jalan.

\section{Konsepsi Pengembangan Struktur Tata Ruang}

Berdasarkan Raperda RTRW Kabupaten Ketapang, 2013-2033, Tata Ruang Wilayah Kabupaten Ketapang yang menjadi acuan dalam pengembangan infrastruktur jalan Kabupaten Ketapang, pada dasarnya mengakomodasi tujuan dan sasaran pembangunan daerah, dikaitkan dengan potensi serta kendala dan limitasi pengembangan yang dihadapi. Penataannya tidak terlepas dari tujuan pengembangan wilayah yang pada dasarnya selaras dengan Rencana Tata Ruang Wilayah Nasional (RTRWN). Pengembangan Tata Ruang WiLayah Kabupaten Ketapang merupakan struktur umum ruang wilayah Kabupaten dalam kerangka pengembangan potensi dan mengatasi permasalahan pokok wilayah untuk mendorong perwujudan tujuan pengembangan tata ruang, dimana dalam proses perkembangan wilayah tersebut tidak terlepas dari pengaruh luar maupun dari dalam wilayah.

\section{Pertimbangan Eksternal}

Aspek ini mengkaji fungsi dan kedudukan Kabupaten Ketapang dalam lingkup Provinsi Kalimantan Barat dan nasional. Adapun beberapa pertimbangan eksternal tersebut adalah :

- Kota Ketapang merupakan salah satu kota setingkat di bawah Kota Pontianak perlu dikembangkan agar pada masa mendatang perkembangan pembangunan di Provinsi Kalimantan Barat dapat tersebar secara merata.

- Tingginya interaksi antara Kabupaten Ketapang dengan Kota Pontianak dan Kabupaten Kubu Raya, Kabupaten Sanggau, serta Provinsi Kalimantan Tengah yang diindikasikan dengan besarnya arus pergerakan pada jalur transportasi Pontianak - Ketapang, Ketapang - Manis Mata - Sukamara, Teluk Batang - Rasau Jaya.

- Interaksi yang terjadi antara wilayah perbatasan Kabupaten Ketapang dengan wilayah Provinsi Kalimantan Tengah pada saat ini dapat merugikan daerah Kabupaten Ketapang karena dapat menyerap sumber daya yang ada. Untuk itu perkembangan daerah Kabupaten Ketapang perlu dipacu untuk mengimbangi keempat daerah tersebut agar sumber daya yang ada tidak terserap keempat wilayah tadi.

- Kabupaten Ketapang mempunyai keterkaitan secara langsung dengan wilayah lain di luar Provinsi Kalimantan Barat (misalnya kegiatan ekspor kayu). Hal ini diharapkan dapat memacu pertumbuhan ekonomi wilayah Kabupaten Ketapang dengan meningkatkan volume perdagangan antarpulau.

- Perlunya pengembangan di sektor pertambangan, pariwisata, pertanian, dan industri agar dapat memacu pertumbuhan wilayah Kabupaten Ketapang, sehingga dapat meningkatkan pertumbuhan wilayah Provinsi Kalimantan Barat.

\section{Pertimbangan Internal}

Aspek ini mengkaji kondisi wilayah Kabupaten Ketapang baik berupa potensi maupun permasalahan yang membutuhkan penanganan lebih lanjut. Adapun pertimbangan-pertimbangan tersebut adalah :

- Kecilnya jumlah penduduk di pusatpusat pemukiman yang berada di wilayah sehingga tidak mendukung untuk percepatan pertumbuhan wilayah itu sendiri. 
Juniardi dan Azwansyah. "Pengembangan infrastruktur jalan di Kabupaten Ketapang"

- Adanya ketimpangan antara perkembangan daerah di wilayah pantai kabupaten (barat) dan daerah pedalaman (timur).

- Perlunya pembangunan prasarana wilayah yang disertai pengisian penduduk beserta kegiatannya pada lahan-lahan potensial untuk pengembangan komoditas baru yang merupakan keunggulan komparatif Kabupaten Ketapang dengan Kabupaten lainnya di wilayah Kalimantan Barat.

- Belum dimanfaatkan dan dikembangkannya potensi wisata yang dimiliki Kabupaten Ketapang secara maksimal.

- Perlunya memantapkan fungsi lindung terutama dari kawasan yang memberikan perlindungan terhadap kawasan hutan lindung dan kawasan resapan air.

- Perlu terciptanya "spesialisasi" dari subwilayah-subwilayah di Kabupaten Ketapang menurut keunggulan kompartifnya sehingga dapat mewujudkan keseimbangan pertumbuhan antar subwilayah.

- Perlunya pemerataan distribusi penduduk serta peningkatan kualitas sumber daya manusia yang masih rendah.

- Perlunya peningkatan aksesibilitas ke daerah pedalaman dan kepulauan untuk meningkatkan penyebaran pelayanan sosial ekonomi bagi masyarakat agar dapat meningkatkan produktivitas dan memacu masyarakat melakukan kegiatan usaha yang lebih produktif, yang pada akhirnya akan mengurangi ketimpangan perkembangan antara wilayah pantai dengan wilayah lainnya.

\section{Konsepsi Pengembangan Transportasi Wilayah}

Berdasarkan Raperda RTRW Kabupaten Ketapang 2013 - 2033 dijelaskan bahwa pengembangan transportasi Kabupaten Ketapang secara umum terdiri dari dua aspek, yaitu penetapan fungsi jaringan transportasi dan rencana pembangunan prasarana tranportasi. Pengembangan transportasi ini terutama transportasi darat memiliki fungsi ganda, yaitu untuk melayani perkembangan daerah yang terjadi saat ini dan merangsang perkembangan daerah ke arah yang diinginkan. Di samping itu, pengembangan transportasi Kabupaten Ketapang juga diarahkan pada pembentukan suatu sistem pergerakan yang serasi dan terpadu antara dua sistem transportasi, yaitu transportasi darat dan sungai.

Batasan klasifikasi fungsi jalan adalah sebagai berikut :

- Sistem Jaringan Jalan Primer, disusun mengikuti ketentuan pengaturan tata ruang dan struktur pengembangan wilayah tingkat nasional yang menghubungkan simpul-simpul jasa distribusi sebagai berikut :

- Dalam satu-satuan wilayah pengembangan menghubungkan secara menerus kota jenjang kesatu, kota jenjang kedua, kota jenjang ketiga dan kota jenjang dibawahnya sampai ke persil.

- Menghubungkan kota jenjang kesatu dengan jenjang kesatu antara satuan wilayah pengembangan.

- Jalan Arteri Primer, menghubungkan kota-kota jenjang kesatu yang terletak berdampingan atau menghubungkan kota jenjang kesatu dengan kota jenjang kedua.

- Jalan Kolektor Primer, menghubungkan kota jenjang kedua dengan kota jenjang kedua atau menghubungkan kota jenjang kedua dengan kota jenjang ketiga.

- Jalan Lokal Primer, menghubungkan kota jenjang kesatu dengan persil, menghubungkan kota jenjang kedua dengan persil, menghubungkan kota jenjang ketiga dengan kota jenjang dibawahnya, kota jenjang ketiga dengan persil dan atau kota kota dibawah jenjang ketiga dengan persil.

- Sistem Jaringan Jalan Sekunder, disusun mengikuti ketentuan pengaturan tata ruang kota menghubungkan kawasan-kawasan yng mempunyai fungsi primer, fungsi sekunder kesatu, fungsi sekunder kedua, ketiga dan seterusnya sampai ke perumahan.

- Jalan Arteri Sekunder, menghubungkan kawasan primer dengan kawasan sekunder ksatu atau menghubungkan kawasan sekunder kedua dengan kawasan sekunder ketiga. 
Juniardi dan Azwansyah. "Pengembangan infrastruktur jalan di Kabupaten Ketapang"

- Jalan Kolektor Sekunder, menghubungkan kawasan sekunder kedua dengan kawasan sekunder kedua dan menghubungkan kawasan sekunder kedua dengan kawasan sekunde ketiga.

- Jalan Lokal Sekunder, menghubungkan kawasan sekunder kesatu dengan perumahan, menghubungkan kawasan sekunder kedua dengan perumahan, menghubungkan kawasan sekunder ketiga atau dibawahnya sampai ke perumahan.

\section{Rencana Pengembangan Struktur Tata Ruang Wilayah}

Berdasarkan Raperda RTRW Kabupaten Ketapang, 2013-2033 dipaparkan bahwa rencana pemanfaatan ruang pada dasarnya berfungsi memberi pedoman penetapan lokasi kegiatan yang sesuai dengan fungsi dominan kawasankawasan di dalam wilayah perencanaan.

\section{Rencana Pemantapan Kawasan Lindung}

Kawasan lindung adalah kawasan yang ditetapkan dengan fungsi utama melindungi kelestarian lingkungan hidup yang mencakup sumber alam, sumber daya buatan dan nilai sejarah serta budaya bangsa guna kepentingan pembangunan berkelanjutan.

Kawasan

lindung

yang direkomendasikan untuk ditetapkan di Kabupaten Ketapang dibagi menjadi 3 (tiga) kawasan, sebagai berikut :

- Kawasan yang memberikan perlindungan kawasan bawahannya, meliputi kawasan hutan lindung seluas $4.954,11 \mathrm{~km}^{2}$, dan kawasan bergambut seluas $658,56 \mathrm{~km}^{2}$.

- Kawasan perlindungan setempat, meliputi kawasan sempadan pantai seluas $46,6 \mathrm{~km}^{2}$, dan kawasan sekitar danau seluas $7,17 \mathrm{~km}^{2}$.

- Kawasan suaka alam dan cagar budaya, yaitu :

- Kawasan Taman Nasional Gunung Palung yang termasuk di dalam Kecamatan Sungai Laur, Nanga Tayap, dan Matan Hilir Utara dengan luas $1.072,35 \mathrm{~km}^{2}$.

- Kawasan Cagar Alam Muara Kendawangan yang termasuk dalam Kecamatan Kendawangan dengan luas $1.659,09 \mathrm{~km}^{2}$.

\section{Rencana \\ Budidaya}

Pengelolaan

Kawasan

Kawasan Budidaya merupakan kawasan yang berpotensi untuk dikembangkan bagi kepentingan produksi daerah. Kawasan yang akan diarahkan pengembangannya di Kabupaten Ketapang terdiri dari 10 (sepuluh) kawasan budidaya yang dikelompokkan dalam 3 (tiga) kelompok yaitu :

- Kawasan budidaya yang terikat dengan lokasi sumber daya yaitu kawasan pertambangan dan pariwisata.

- Kawasan budidaya yang tidak terikat dengan lokasi sumber daya yaitu kawasan yang mempunyai alternatif untuk dipindahkan yaitu kawasan perikanan, pertanian lahan basah, pertanian lahan kering, perkebunan, peternakan, dan kehutanan.

- Kawasan budidaya yang mempunyai ketergantungan terhadap potensi sumber daya, lokasi pemasaran, pola pusat pelayanan serta jalur dan simpul transportasi orang dan barang yaitu kawasan pemukiman dan industri.

\section{Rencana Pengembangan Sistem Pembangunan dan Sistem Pemukiman Perkotaan Pedesaan}

Berdasarkan hasil kajian analisis dan pertimbangan lainnya maka di Kabupaten Ketapang terbagi menjadi 3 (tiga) wilayah pembangunan sebagai berikut :

- Sub Wilayah Pembangunan I (SWP I), meliputi Kecamatan Kendawangan, Matan Hilir Selatan, Matan Hilir Utara, dengan pusat pengembangan di Kota Ketapang.

- Sub Wilayah Pembangunan II (SWP II), meliputi Kecamatan Simpang Hulu, Sungai Laur, dan Sandai, dengan pusat pengembangan di Kota Sandai.

- Sub Wilayah Pembangunan III (SWP III), meliputi Kecamatan Nanga Tayap, Tumbang Titi, Marau, Jelai Hulu, dan Manis Mata, dengan pusat pengembangan di Kota Tumbang Titi.

Ditinjau dari fungsinya dalam lingkup wilayah, secara umum pengembangan kota diarahkan sebagai pusat-pusat pelayanan regional, diantaranya yaitu :

a. Pusat pemukiman penduduk 
Juniardi dan Azwansyah. "Pengembangan infrastruktur jalan di Kabupaten Ketapang"

b. Pusat pelayanan sosial dan administrasi wilayah belakangnya

c. Pusat komunikasi antar wilayah

d. Pusat kegiatan manufaktur

Kelengkapan fungsi-fungsi utama kota pada dasarnya tergantung dari hirarki kota yang bersangkutan. Berdasarkan hasil analisis sistem kota-kota yang ada di Kabupaten Ketapang diperoleh 3 hirarki / orde kota yang berperan sebagai pusat pelayanan pertumbuhan kota-kota yang mengganti pusat pelayanan adalah :

a. Kota orde I merupakan kota dengan skala pelayanan regional, yang memiliki jangkauan pelayanan mencakup seluruh wilayah kabupaten adalah Kota Ketapang.

b. Kota orde II merupakan kota dengan skala pelayanan subregional, dimana jangkauan pelayanannya mencakup beberapa kecamatan yaitu Sandai dan Tumbang Titi.

c. Kota Orde III merupakan kota dengan skala pelayanan lokal, dimana kota ini hanya melayani wilayah belakang dalam satu wilayah kecamatan yaitu Kendawangan, Pesaguan, Kuala Tolak, Manis Mata, Marau, Nanga Tayap, Balai Berkuak.

\section{Rencana Pengembangan Sistem Prasarana Wilayah}

Sistem pengembangan prasarana wilayah merupakan penunjang dalam pengembangan kawasan budidaya dan sistem pemukiman di wilayah Kabupaten Ketapang. Prasarana penunjang tersebut terdiri dari :

- Sistem pelayanan transportasi

- Sistem pelayanan listrik

- Sistem pelayanan pos dan telekomunikasi

- Sistem pelayanan air bersih

- Sistem pelayanan pengairan / irigasi

\section{Rencana Pengembangan Kawasan Prioritas}

Wilayah-wilayah prioritas yang terdapat di Kabupaten Ketapang adalah :

- Wilayah prioritas A

Pengembangan wilayah ini ditujukan untuk meningkatkan pertumbuhan kawasan terbelakang disekitarnya dan memantapkan aksesibilitas untuk menunjang perkembangan kawasan DAS Lawang Darah.
- Wilayah prioritas B

Pengembangan wilayah ini ditujukan untuk memacu pertumbuhan kawasan terisolir di sekitarnya dan menunjang perkembangan Kawasan ekowisata Gunung Palung yang berada di Kecamatan Simpang Hulu.

- Wilayah prioritas $\mathrm{C}$

Pengembangan wilayah ini dimaksudkan untuk mengembalikan kelestarian alam di wilayah ini yang sebagian besar telah mengalami kerusakan. Wilayah ini berada di Kecamatan Kendawangan.

- Wilayah prioritas D

Pengembangan wilayah ini dimaksudkan untuk memacu perkembangan daerah subpusat pengembangan utama SWP II.

- Wilayah prioritas $\mathrm{E}$

Pengembangan wilayah ini ditujukan untuk meningkatkan pelayanan untuk kegiatan produksi dan pemasaran, mengingat wilayah ini berbatasan dengan Provinsi Kalimantan Tengah.

- Wilayah prioritas $\mathrm{F}$

Pengembangan wilayah ini ditujukan untuk meningkatkan perekonomian masyarakat karena wilayah ini memiliki potensi pada lahan pertanian basah/kering, peternakan, perikanan, dan perkebunan.

- Wilayah prioritas $\mathrm{G}$

Pengembangan wilayah ini dimaksudkan untuk memacu pertumbuhan keseluruhan wilayah Kabupaten Ketapang. Wilayah ini memiliki potensi di sektor industri, perdagangan, jasa dan keuangan serta perbankan.

- Wilayah prioritas $\mathrm{H}$

Pengembangan wilayah ini dimaksudkan untuk membentuk kota baru untuk menjadi ibukota kecamatan. Wilayah ini berada di Kecamatan Matan Hilir Utara dan Kecamatan simpang Dua.

\section{Pusat-pusat Kegiatan Kabupaten Ketapang}

Pusat-pusat kegiatan, meliputi (Raperda RTRW Kabupaten Ketapang, 2013-2033) :

a. PKW yaitu Kota Ketapang;

b. PKL yaitu Kota Balai Berkuak, Sandai, Tumbang Titi, Manismata, dan Kendawangan; 
Juniardi dan Azwansyah. "Pengembangan infrastruktur jalan di Kabupaten Ketapang"

c. PPK yaitu Simpang Dua, Aur Kuning, tersebut, hal mendasar yang perlu Menyumbung, Nanga Tayap, Pebihingan, Sungai Melayu, Riam, Marau, Air Upas, Sukaraja, Pesaguan, Sei Awan Kiri, dan Kuala Tolak; dan

d. PPL yaitu Pangkalan Teluk, Sungai Kelik, Betenung, Tanjungpura, Pelang, Riam Danau, Tanjung, Serengkah, Nanga Kelampai, Sukaramai, Terusan, Air Hitam Besar, Sepotong, Semandang Hulu, Meraban dan Cinta Manis.

\section{Persebaran Penduduk}

Penduduk di Kabupaten Ketapang yang tersebar di 20 kecamatan, persebarannya tidak merata. Persebaran penduduk yang tidak merata akan menghambat lancarnya proses pembangunan dan akan menciptakan ketidakseimbangan daya dukung dan daya tampung lingkungan (BPS Kabupaten Ketapang, 2012).

Persebaran penduduk yang tidak merata disebabkan karena penduduk cenderung memilih tempat tinggal pada daerah-daerah yang sudah terbuka dan sudah berkembang dimana pembangunan ekonominya lebih maju, peluang kerja tinggi, dan sarana dan prasarana cukup tersedia.

dilakukan oleh pemerintah dalam rangka pemerataan persebaran penduduk adalah membangun jalan baru, peningkatan jalan dan penggantian jembatan.

Mengingat Kabupaten Ketapang sebagai salah satu daerah penerima transmigran, maka dalam proses pemerataan penduduk, para transmigran lebih tepat diarahkan ke kecamatan yang keadaan penduduknya masih jarang $( \pm 10$ jiwa $\left./ \mathrm{km}^{2}\right)$, seperti Kecamatan Hulu Sungai, Kendawangan, Simpang Dua, Manis Mata, Marau, dan Sungai Laur.

Pada tahun tahun 2011 jumlah penduduk Kabupaten Ketapang adalah sebanyak 437.613 jiwa (227 697 jiwa berjenis kelamin laki-laki dan 209916 jiwa berjenis kelamin perempuan).

Kecamatan dengan jumlah penduduk terbesar adalah Kecamatan Delta Pawan yaitu sekitar 73.938 jiwa atau 16,9\% dari total jumlah penduduk Kabupaten Ketapang. Sedangkan kecamatan dengan jumlah penduduk terkecil adalah Kecamatan Singkup yaitu sekitar 6.305 jiwa atau $1,44 \%$ dari total jumlah penduduk Kabupaten Ketapang.

Jumlah dan persentase penduduk menurut kecamatan di Kabupaten Ketapang dapat dilihat pada tabel 1.

Bertitik tolak dari kecenderungan

Tabel 1. Jumlah Penduduk Menurut Kecamatan di Kabupaten Ketapang Tahun 2011

\begin{tabular}{|l|c|c|}
\hline \multirow{2}{*}{\multicolumn{1}{c|}{ Kecamatan }} & \multicolumn{2}{c|}{ Jumlah } \\
\cline { 2 - 3 } & Penduduk & $\%$ \\
\hline Kendawangan & 33111 & 7,57 \\
\hline Manis Mata & 25439 & 5,81 \\
\hline Marau & 12297 & 2,81 \\
\hline Singkup & 17001 & 1,44 \\
\hline Air Upas & 15895 & 3,88 \\
\hline Jelai Hulu & 23414 & 5,63 \\
\hline Tumbang Titi & 23414 & 1,05 \\
\hline Pemahan & 11931 & 2,73 \\
\hline Sungai Melayu Rayak & 31046 & 7,09 \\
\hline Matan Hilir Selatan & 36098 & 8,25 \\
\hline Benua Kayong & 14943 & 3,41 \\
\hline Matan Hilir Utara & 73938 & 16,9 \\
\hline Delta Pawan & 13347 & 3,05 \\
\hline Muara Pawan & 27989 & 6,40 \\
\hline Nanga Tayap & 25106 & 5,74 \\
\hline Sandai & 11684 & 2,67 \\
\hline Hulu Sungai & & \\
\hline
\end{tabular}


Juniardi dan Azwansyah. "Pengembangan infrastruktur jalan di Kabupaten Ketapang"

\begin{tabular}{|c|c|c|}
\hline \multirow{2}{*}{ Kecamatan } & \multicolumn{2}{|c|}{ Jumlah } \\
\hline & Penduduk & $\%$ \\
\hline Sungai Laur & 17272 & 3,95 \\
\hline Simpang Hulu & 28572 & 6,53 \\
\hline Simpang Dua & 7650 & 1,75 \\
\hline Total & 437613 & 100 \\
\hline
\end{tabular}

(Sumber : BPS Kabupaten Ketapang, 2012)

\section{Konsep Pemodelan Bangkitan dan Tarikan Pergerakan}

Tahapan pemodelan bangkitan pergerakan bertujuan meramalkan jumlah pergerakan pada setiap zona asal dengan menggunakan data rinci mengenai tingkat bangkitan pergerakan, atribut sosialekonomi, serta tata guna lahan (Tamin, 2008).

Lubis (2012) menuliskan bahwa dalam pemodelan bangkitan pergerakan, metode analisis regresi linear berganda (Multiple Linear Regression Analysis) yang paling sering digunakan. Metode analisis regresi linear berganda digunakan untuk menghasilkan hubungan dalam bentuk numerik dan untuk melihat bagaimana variabel saling berkait.

Ada beberapa asumsi statistik harus dipertimbangkan dalam menggunakan metode analisis regresi linear berganda, sebagai berikut:

1. Variabel terikat $(Y)$ adalah merupakan fungsi linear dari variabel bebas $(X)$.

2. Variabel, terutama variabel bebas adalah tetap atau telah diukur tanpa galat.

3. Tidak ada korelasi antara variabel bebas.

Persamaan regresi linier yang digunakan untuk membuat hubungan jumlah pergerakan dengan beberapa variabel yang berpengaruh. Bentuk persamaan dasar yang digunakan pada analisis regresi berganda adalah :

$$
\begin{array}{ll}
Y=a_{0}+a_{1} X_{1}+a_{2} X_{2}+\ldots \ldots+a_{n} X_{n} \\
\text { dengan: } \\
\begin{array}{cl}
Y & =\text { variabel tidak bebas } \\
X_{1}, X_{2}, X_{n} & =\text { variabel bebas } \\
a_{1}, a_{2}, a_{n} & =\text { koefisien regresi } \\
a_{0} & =\text { konstanta }
\end{array}
\end{array}
$$

\section{Model Distribusi Pergerakan}

Model sintetis yang cukup terkenal dan sering digunakan dalam studi perencanaan transportasi adalah model gravity yang diturunkan dari hukum gravitasi.

Model gravity memiliki bentuk umum sebagai berikut :

Tid = Oi. Dd. Ai. Bd. F (Cid)

Dengan syarat batasan ;

$$
\mathrm{Bd}=\frac{1}{\sum_{i}(\text { Ai.Oi.fid })} \text { untuk semua d }
$$

dan

$$
\mathrm{Ai}=\frac{1}{\sum_{d}(\text { Ai.Oi.fid })} \text { untuk semua } \mathrm{i}
$$

Dimana :

Tid $=$ total pergrakan pada masa mendatang dari zona asal I ke zona tujuan

Oi = pergerakan yang berasal dari zona I ke zona d

$\mathrm{Dd}=$ pergerakan yang berakhir di zona d

$F($ Cid $)=$ ukuran aksesibelity (kemudahan) antara zona i dengan zona $d$ dan sebaliknya

$$
\begin{aligned}
& \mathrm{Bd}=\text { konstanta atau faktor } \\
& \text { penyeimbang } \\
& \mathrm{Ai}=\text { konstanta atau faktor }
\end{aligned}
$$

\section{Analisis Kinerja Jalan}

Perhitungan kinerja jalan berdasarkan Manual Kapasitas Jalan Indonesia (MKJI) 1997. Dalam st(Rli) ini, kinerja jalan digambarkan dengan derajat kejenuhan (DS) yaitu rasio volume lalu lintas (Q) dengan kapasitas jalan (C) (Dirjen BM, 1997). Volume lalu lintas di peroleh dari hasil survei lalu lintas. Sedangkan kapasitas jalan diperoleh berdasarkan data geomterik dan kondisi lingkungan jalan yang selanjutnya dioleh menggunakan rumus umum yaitu :

$\mathrm{C}=$ Co $\times$ FCw $\times$ FCsp $\times$ FCsf (smp/jam)

Dimana : 
Juniardi dan Azwansyah. "Pengembangan infrastruktur jalan di Kabupaten Ketapang"

$\begin{aligned} & \text { C }=\text { Kapasitas } \\ & \text { Co }=\text { Kapasitas dasar (smp/jam) } \\ & \text { FCw }= \text { Faktor penyesuaian akibat } \\ & \text { lebar lajur lalu-lintas } \\ & \text { FCsp }=\begin{array}{l}\text { Faktor penyesuaian } \\ \text { pemisahan arah }\end{array} \\ & \text { FCsf }=\begin{array}{l}\text { Faktor penyesuaian akibat } \\ \text { hambatan samping }\end{array}\end{aligned}$

Nilai derajat kejenuhan (DS) yang di syaratkan adalah tidak melebih 0,8 (MKJI, 1997).
Tahap pertama yang harus dilakukan dari setiap metode analisis yang ada yaitu melakukan uji korelasi antara sesama peubah bebas dan antara peubah bebas dengan peubah tidak bebas. Hal ini dilakukan sesuai dengan persyaratan statistik yang harus dipenuhi, yaitu sesama peubah bebas tidak boleh mempunyai korelasi. Korelasi antara peubah bebas dan peubah tidak bebas untuk bangkitan dan tarikan pergerakan masing-masing dapat dilihat pada Tabel 1. dan 2.

\section{Hasil dan Pembahasan}

Tabel 1. Matriks Korelasi antara Peubah Bebas dan Peubah Tidak Bebas Bangkitan Pergerakan

\begin{tabular}{|l|c|c|c|c|c|c|c|}
\hline \multicolumn{1}{|c|}{ Variabel } & $\mathrm{Yb}$ & $\mathrm{X} 1$ & $\mathrm{X} 2$ & $\mathrm{X} 3$ & $\mathrm{X} 4$ & $\mathrm{X} 5$ & $\mathrm{X} 6$ \\
\hline Bangkitan, Y1 & 1,000 & & & & & & \\
\hline Jlh penduduk, X1 & 0,431 & 1,000 & & & & & \\
\hline Jlh Sekolah, X2 & 0,234 & 0,773 & 1,000 & & & & \\
\hline Luas lahan perkebunan, X3 & 0,185 & $-0,181$ & $-0,121$ & 1,000 & & & \\
\hline Jlh siswa, X4 & 0,388 & 0,964 & 0,824 & $-0,198$ & 1,000 & & \\
\hline JIh perusahaan/usaha. X5 & 0,348 & 0,890 & 0,769 & $-0,209$ & 0,898 & 1,000 & \\
\hline Jlh sarana kesehatan, X6 & 0,499 & 0,479 & 0,661 & 0,317 & 0,464 & 0,407 & 1,000 \\
\hline
\end{tabular}

(Sumber : Analisis data, 2013)

Tabel 2. Matriks Korelasi antara Peubah Bebas dan Peubah Tidak Bebas Tarikan Pergerakan

\begin{tabular}{|l|c|c|c|c|c|c|c|}
\hline \multicolumn{1}{|c|}{ Variabel } & $\mathrm{Yt}$ & $\mathrm{X} 1$ & $\mathrm{X} 2$ & $\mathrm{X} 3$ & $\mathrm{X} 4$ & $\mathrm{X} 5$ & $\mathrm{X} 6$ \\
\hline Tarikan, Yt & 1,000 & & & & & & \\
\hline Jlh penduduk, X1 & 0,777 & 1,000 & & & & & \\
\hline Jlh Sekolah, X2 & 0,806 & 0,773 & 1,000 & & & & \\
\hline Luas lahan perkebunan, X3 & 0,158 & $-0,181$ & $-0,121$ & 1,000 & & & \\
\hline Jlh siswa, X4 & 0,750 & 0,964 & 0,824 & $-0,198$ & 1,000 & & \\
\hline Jlh perusahaan/usaha. X5 & 0,676 & 0,890 & 0,769 & $-0,209$ & 0,898 & 1,000 & \\
\hline Jlh sarana kesehatan, X6 & 0,924 & 0,479 & 0,661 & 0,317 & 0,464 & 0,407 & 1,000 \\
\hline
\end{tabular}

(Sumber : Analisis data)

Berdasarkan Tabel 1 dan Tabel 2 diketahui bahwa variabel tak bebas $\mathrm{Yb}$ memiliki hubungan yang lemah dengan semua variabel bebas yang dapat dilihat dari nilai korelasi di bawah 0,5. Sedangkan variabel tak bebas $\mathrm{Yt}$ hampir semua memiliki hubungan yang kuat dengan variabel bebas dan hanya memiliki hubungan yang lemah dengan variabel bebas X3.

Pemodelan bangkitan pergerakan dengan metode analisis langkah - demi langkah tipe 1, tipe 2, dan coba-coba masing-masing dapat dilihat pada Tabel 3, Tabel 4 dan Tabel 5.

Tabel 3. Pemodelan Bangkitan Pergerakan dengan Metode Analisis Langkah-demi-langkah Tipe 1

\begin{tabular}{|c|c|r|r|r|r|r|r|}
\hline \multirow{2}{*}{ Variabel } & Nilai & \multicolumn{7}{|c|}{ Tahap } \\
\cline { 3 - 8 } & Diharapkan & $\mathbf{1}$ & $\mathbf{2}$ & \multicolumn{1}{|c|}{$\mathbf{3}$} & \multicolumn{1}{c|}{$\mathbf{4}$} & \multicolumn{1}{c|}{$\mathbf{5}$} & $\mathbf{6}$ \\
\hline \hline Intercept & 0 & 4913,7633 & 5096,2071 & 5266,4621 & 5313,8725 & 5299,1455 & 5410,7373 \\
\hline x1 & + & 0,0260 & 0,0890 & 0,0547 & 0,0414 & 0,0331 & \\
\hline x2 & + & $-55,3920$ & & & & & \\
\hline x3 & + & 0,0021 & 0,0203 & 0,0215 & 0,0223 & & \\
\hline x4 & + & 0,2492 & $-0,1756$ & & & & \\
\hline x5 & + & 0,3244 & $-0,1168$ & $-0,2636$ & & & \\
\hline x6 & + & 345,7436 & 152,6427 & 149,2139 & 149,1138 & 186,4411 & 245,0122 \\
\hline R Square & $>0,5$ & 0,4653 & 0,3230 & 0,3160 & 0,3134 & 0,5453 & 0,2494 \\
\hline
\end{tabular}


Juniardi dan Azwansyah. "Pengembangan infrastruktur jalan di Kabupaten Ketapang" (Sumber : Analisis data, 2013)

Tabel 4. Pemodelan Bangkitan Pergerakan dengan Metode Analisis Langkah-demi-langkah Tipe 2

\begin{tabular}{|c|c|r|r|r|r|r|r|}
\hline \multirow{2}{*}{ Variabel } & \multirow{2}{*}{$\begin{array}{c}\text { Nilai } \\
\text { Diharapkan }\end{array}$} & \multicolumn{1}{|c|}{ Tahap } \\
\cline { 3 - 8 } & & $\mathbf{1}$ & \multicolumn{1}{|c|}{$\mathbf{2}$} & \multicolumn{1}{|c|}{$\mathbf{3}$} & $\mathbf{4}$ & \multicolumn{1}{|c|}{$\mathbf{5}$} & $\mathbf{6}$ \\
\hline \hline Intercept & 0 & 4913,7633 & 4908,2161 & 5054,3401 & 5059,4335 & 5299,1455 & 5410,7373 \\
\hline x1 & + & 0,0260 & 0,0254 & 0,0882 & 0,0850 & 0,0331 & \\
\hline x2 & + & $-55,3920$ & $-55,8328$ & & & & \\
\hline x3 & + & 0,0021 & & & & & \\
\hline x4 & + & 0,2492 & 0,2506 & $-0,1949$ & $-0,2152$ & & \\
\hline x5 & + & 0,3244 & 0,3241 & $-0,1562$ & & & \\
\hline x6 & + & 345,7436 & 350,5793 & 186,3701 & 187,2617 & 186,4411 & 245,0122 \\
\hline R Square & $>0,5$ & 0,4653 & 0,4652 & 0,3100 & 0,3092 & 0,5453 & 0,2494 \\
\hline
\end{tabular}

(Sumber: Analisis data, 2013)

Tabel 5. Pemodelan Bangkitan Pergerakan dengan Metode Analisis Coba-coba

\begin{tabular}{|c|c|r|r|r|r|r|r|}
\hline \multirow{2}{*}{ Variabel } & \multirow{2}{*}{$\begin{array}{c}\text { Nilai } \\
\text { Diharapkan }\end{array}$} & \multicolumn{1}{|c|}{ Tahap } & \multicolumn{1}{|c|}{$\mathbf{4}$} & $\mathbf{5}$ \\
\cline { 3 - 8 } & & $\mathbf{1}$ & $\mathbf{2}$ & $\mathbf{3}$ & $\mathbf{4}$ & $\mathbf{5}$ \\
\hline \hline Intercept & 0 & 4913,7633 & 6195,3065 & 6730,8725 & 7142,2086 & 7142,7642 & 6920,7710 \\
\hline x1 & + & 0,0260 & 0,0927 & & & & \\
\hline x2 & + & $-55,3920$ & $-16,2123$ & $-19,7008$ & $-17,0088$ & $-16,8063$ & \\
\hline x3 & + & 0,0021 & 0,0425 & 0,0444 & & & \\
\hline x4 & + & 0,2492 & $-0,0060$ & 0,3287 & 0,3052 & 0,3210 & 0,2051 \\
\hline x5 & + & 0,3244 & $-0,0204$ & 0,2070 & 0,0836 & & \\
\hline x6 & + & 345,7436 & & & & & \\
\hline R Square & $>0,5$ & 0,4653 & 0,2850 & 0,2529 & 0,1735 & 0,1733 & 0,1505 \\
\hline
\end{tabular}

(Sumber : Analisis data, 2013)

Berdasarkan rekapitulasi hasil analisis regresi pada Tabel 3 sampai dengan Tabel 5, maka dapat ditentukan bahwa model bangkitan pergerakan penumpang adalah hasil analisis dari Metode Langkah-DemiLangkah Tipe 1 dan 2 pada tahap 5, dimana model bangkitan pergerakan penumpang dipengaruhi oleh variabel jumlah penduduk (X1) dan jumlah sarana kesehatan (X6). Model ini dipilih karena memiliki koefisien regresi sesuai yang diharapkan yaitu positif dan nilai determinan $\left(R^{2}\right)$ sebesar 0,5453 yang berarti diatas 0,5 .

Tabel 6. Pemodelan Tarikan Pergerakan Metode Analisis Langka-Demi-Langkah Tipe 1

\begin{tabular}{|c|c|c|c|c|c|c|c|}
\hline \multirow{2}{*}{ Variabel } & \multirow{2}{*}{$\begin{array}{c}\text { Nilai } \\
\text { Diharapkan }\end{array}$} & \multicolumn{6}{|c|}{ Tahap } \\
\hline & & 1 & 2 & 3 & 4 & 5 & 6 \\
\hline Intercept & 0 & 648,6504 & 648,9420 & 650,1078 & 655,2295 & 653,1981 & 963,7451 \\
\hline $\mathrm{X} 1$ & + & 0,0948 & 0,0949 & 0,0943 & 0,0932 & 0,0920 & \\
\hline $\mathrm{X} 2$ & + & $-0,0885$ & & & & & \\
\hline X3 & + & 0,0029 & 0,0030 & 0,0030 & 0,0031 & & \\
\hline $\mathrm{X} 4$ & + & 0,0001 & $-0,0005$ & $-0,0046$ & & & \\
\hline$\times 5$ & + & $-0,0309$ & $-0,0316$ & & & & \\
\hline$x 6$ & + & 557,9811 & 557,6725 & 557,7406 & 557,6499 & 562,7986 & 725,7951 \\
\hline $\begin{array}{c}\mathrm{R} \\
\text { Square } \\
\end{array}$ & $>0,5$ & 0,9997 & 0,9997 & 0,9997 & 0,9997 & 0,9996 & 0,8546 \\
\hline
\end{tabular}

(Sumber : Analisis data, 2013)

Tabel 7. Pemodelan Tarikan Pergerakan Metode Analisis Langka-Demi-Langkah Tipe 2

\begin{tabular}{|c|c|c|r|r|r|r|r|}
\hline \multirow{2}{*}{ Variabel } & \multirow{2}{*}{$\begin{array}{c}\text { Nilai } \\
\text { Diharapkan }\end{array}$} & \multicolumn{1}{|c|}{ Tahap } \\
\cline { 3 - 8 } & $\mathbf{1}$ & $\mathbf{2}$ & \multicolumn{1}{c|}{$\mathbf{3}$} & \multicolumn{1}{c|}{$\mathbf{4}$} & \multicolumn{1}{c|}{$\mathbf{5}$} & $\mathbf{6}$ \\
\hline \hline Intercept & 0 & 4913,7633 & 640,9778 & 641,4863 & 641,6720 & 1273,4965 & 963,7450 \\
\hline $\mathrm{X} 1$ & + & 0,0260 & 0,0940 & 0,0932 & 0,0931 & & \\
\hline $\mathrm{X} 2$ & + & $-55,3920$ & $-0,6981$ & $-0,8761$ & $-0,8844$ & 35,0837 & \\
\hline
\end{tabular}


Juniardi dan Azwansyah. "Pengembangan infrastruktur jalan di Kabupaten Ketapang"

\begin{tabular}{|c|c|c|r|r|r|r|r|}
\hline X3 & + & 0,0021 & & & & & \\
\hline X4 & + & 0,2492 & 0,0022 & $-0,0003$ & & & \\
\hline X5 & + & 0,3244 & $-0,0314$ & & & & \\
\hline X6 & + & 345,7436 & 564,6696 & 565,3636 & 565,3871 & 545,7153 & 725,7951 \\
\hline R Square & $>0,5$ & 0,465 & 0,9996 & 0,9996 & 0,9996 & 0,9225 & 0,8546 \\
\hline
\end{tabular}

(Sumber: Analisis data, 2013)

Tabel 8. Pemodelan Tarikan Pergerakan Metode Analisis Coba-Coba

\begin{tabular}{|c|c|r|r|r|r|r|r|}
\hline \multirow{2}{*}{ Variabel } & \multirow{2}{*}{$\begin{array}{c}\text { Nilai } \\
\text { Diharapkan }\end{array}$} & \multicolumn{1}{|c|}{ Tahap } \\
\cline { 2 - 8 } & $\mathbf{1}$ & \multicolumn{1}{|c|}{$\mathbf{2}$} & \multicolumn{1}{c|}{$\mathbf{3}$} & \multicolumn{1}{c|}{$\mathbf{4}$} & \multicolumn{1}{c|}{$\mathbf{5}$} & $\mathbf{6}$ \\
\hline \hline Intercept & 0 & 4913,7633 & 2716,8794 & 3886,9898 & 4542,3531 & 4921,2213 & 7388,2071 \\
\hline X1 & + & 0,0260 & 0,2025 & & & & \\
\hline X2 & + & $-55,3920$ & 63,1420 & 55,5203 & & & \\
\hline X3 & + & 0,0021 & 0,0681 & 0,0723 & 0,0789 & 0,0770 & 0,0389 \\
\hline X4 & + & 0,2492 & $-0,4116$ & 0,3195 & 0,6420 & & \\
\hline X5 & + & 0,3244 & $-0,5874$ & $-0,0905$ & 0,2256 & 2,7418 & \\
\hline X6 & + & 345,7436 & & & & & \\
\hline R Square & $>0,5$ & 0,4653 & 0,8164 & 0,7564 & 0,6614 & 0,5503 & 0,0250 \\
\hline
\end{tabular}

(Sumber : Analisis data, 2013)

Hasil analisis model tarikan pergerakan penumpang seperti terlihat pada tabel 6 sampai dengan tabel 8 . Model tarikan pergerakan penumpang adalah hasil analisis dari Metode Langkah-DemiLangkah Tipe 1 pada tahap 5, dimana model bangkitan pergerakan penumpang dipengaruhi oleh variabel jumlah penduduk (X1) dan jumlah sarana kesehatan (X6). Model ini dipilih karena memiliki koefisien regresi sesuai yang diharapkan yaitu positif dan nilai determinan $\left(R^{2}\right)$ sangat signifikan sebesar 0,9996 yang berarti diatas 0,5.

Berdasarkan analisis bangkitan dan tarikan pergerakan penumpang seperti diuraikan diatas, maka didapat formula modal bangkitan dan tarikan penumpang di Kabupaten Ketapang dapat direkap dalam tabel 10.

- Model bangkitan pergerakan :

$\mathrm{Yb}=5299,1455+0,0331 \cdot \mathrm{X} 1+$ 186,4411.X6

- Model tarikan pergerakan :

\begin{abstract}
$\mathrm{Yt}=653,1981+0,0920 . \mathrm{X} 1+$ $562,7986 . X 6$

Dimana :

$\mathrm{Yb}=$ Jumlah bangkitan pergerakan penumpang pada suatu zona yang ditinjau

Yt $=$ Jumlah tarikan pergerakan penumpang pada suatu zona yang ditinjau

X1 = Jumlah Penduduk pada zona yang ditinjau

X6 = Jumlah Sarana Kesehatan pada zona yang ditinjau
\end{abstract}

Berdasarkan model tersebut di atas, dengan diketahui jumlah penduduk dan sarana kesehatan dapat diestimasi bangkitan dan tarikan pergerakan kendaraan setiap kecamatan di Kabupaten.

Pada studi ini dihasilkan prediksi jumlah bangkitan dan tarikan pergerakan kendaraan setiap kecamatan di Kabupaten Ketapang 2023 yang dapat lihat pada Tabel 9.

Tabel 9. Prediksi Jumlah Bangkitan dan Tarikan Pergerakan Kendaraan

Setiap Kecamatan di Kabupaten Ketapang

\begin{tabular}{|c|l|c|c|l|c|}
\hline NO & \multicolumn{1}{|c|}{ KECAMATAN } & $\mathbf{2 0 2 3}$ & NO & KECAMATAN & $\mathbf{2 0 2 3}$ \\
\hline 1 & Kendawangan & 10660 & 11 & Benua Kayong & 7440 \\
\hline 2 & Manis mata & 11947 & 12 & Matan Hilir Utara & 6797 \\
\hline 3 & Marau & 10014 & 13 & Delta Pawan & 13236 \\
\hline 4 & Singkup & 7440 & 14 & Muara Pawan & 8085 \\
\hline 5 & Air Upas & 7440 & 15 & Nanga Tayap & 11947 \\
\hline 6 & Jelai Hulu & 8085 & 16 & Sandai & 10660 \\
\hline 7 & Tumbang Titi & 10660 & 17 & Hulu Sungai & 6156 \\
\hline 8 & Pemahan & 4865 & 18 & Sungai Laur & 8727 \\
\hline 9 & Sungai Melayu Rayak & 10014 & 19 & Simpang Dua & 8085 \\
\hline
\end{tabular}


Juniardi dan Azwansyah. "Pengembangan infrastruktur jalan di Kabupaten Ketapang"

10 Matan Hilir Selatan \begin{tabular}{l|l|l|l}
9373 & 20 & Simpang Hulu
\end{tabular} 6156

(Sumber : Analisis data, 2013)

Data jumlah bangkitan dan tarikan pergerakan kendaraan seperti pada Tabel 9 dijadikan data input untuk menganalisis distribusi pergerakan kendaraan antar kecamatan di Kabupaten Ketapang.
Dengan menggunakan Metode Gravity seperti dijelaskan pada bagian 2.8 , maka dapat diperoleh distribusi pergerakan kendaraan pada tahun 2023.

Tabel 10. Distribusi Pergerakan Kendaraan Antar Kecamatan di Kabupaten Ketapang Tahun 2023

\begin{tabular}{|c|c|c|c|c|c|c|c|c|c|c|c|}
\hline Zona & 1 & 2 & 3 & 4 & 5 & 6 & 7 & 8 & 9 & 10 & 11 \\
\hline 1 & 0.00 & 574.16 & 553.29 & 275.22 & 234.37 & 357.50 & 425.97 & 99.89 & 438.50 & 2192.60 & 1010.40 \\
\hline 2 & 761.16 & 0.00 & 1647.99 & 1500.42 & 2505.82 & 1064.81 & 992.80 & 148.60 & 416.31 & 179.18 & 138.63 \\
\hline 3 & 834.04 & 1873.90 & 0.00 & 898.25 & 764.90 & 1166.76 & 1087.86 & 162.82 & 456.17 & 196.34 & 151.90 \\
\hline 4 & 475.03 & 1953.47 & 1028.49 & 0.00 & 825.41 & 664.53 & 619.60 & 92.74 & 259.81 & 111.83 & 86.52 \\
\hline 5 & 367.35 & 2962.74 & 795.35 & 749.58 & 0.00 & 513.89 & 479.14 & 71.71 & 200.92 & 86.48 & 66.91 \\
\hline 6 & 520.88 & 1170.31 & 1127.76 & 560.99 & 477.70 & 0.00 & 1119.18 & 167.51 & 469.30 & 201.99 & 156.28 \\
\hline 7 & 540.51 & 950.28 & 915.74 & 455.52 & 387.89 & 974.68 & 0.00 & 497.63 & 1394.16 & 600.07 & 464.25 \\
\hline 8 & 202.57 & 227.30 & 219.04 & 108.96 & 92.78 & 233.13 & 795.25 & 0.00 & 522.49 & 224.89 & 173.99 \\
\hline 9 & 604.76 & 433.11 & 417.36 & 207.61 & 176.79 & 444.23 & 1515.32 & 355.36 & 0.00 & 671.40 & 519.44 \\
\hline 10 & 2144.13 & 132.18 & 127.37 & 63.36 & 53.95 & 135.57 & 462.45 & 108.45 & 476.05 & 0.00 & 1096.94 \\
\hline 11 & 970.41 & 100.43 & 96.78 & 48.14 & 41.00 & 103.01 & 351.39 & 82.40 & 361.73 & 1077.34 & 0.00 \\
\hline 12 & 477.38 & 59.74 & 57.57 & 28.64 & 24.39 & 61.28 & 209.03 & 62.43 & 177.95 & 529.98 & 566.35 \\
\hline 13 & 1193.57 & 123.53 & 119.04 & 59.21 & 50.42 & 126.70 & 432.20 & 101.35 & 444.91 & 1325.09 & 1416.01 \\
\hline 14 & 951.48 & 98.48 & 94.90 & 47.20 & 40.20 & 101.00 & 344.54 & 80.80 & 354.67 & 1056.32 & 1128.80 \\
\hline 15 & 380.36 & 426.81 & 411.29 & 204.59 & 174.22 & 437.76 & 1493.27 & 445.97 & 981.09 & 422.27 & 325.86 \\
\hline 16 & 211.42 & 237.23 & 228.61 & 113.72 & 96.83 & 243.32 & 830.00 & 247.89 & 545.32 & 234.71 & 181.59 \\
\hline 17 & 107.65 & 120.79 & 116.40 & 57.90 & 49.31 & 123.89 & 422.62 & 126.22 & 277.66 & 119.51 & 92.46 \\
\hline 18 & 92.45 & 103.74 & 99.97 & 49.73 & 42.34 & 106.40 & 362.95 & 108.40 & 238.46 & 102.64 & 79.41 \\
\hline 19 & 57.86 & 64.93 & 62.57 & 31.12 & 26.50 & 66.60 & 227.17 & 67.85 & 149.25 & 64.24 & 49.70 \\
\hline 20 & 33.41 & 37.49 & 36.12 & 17.97 & 15.30 & 38.45 & 131.16 & 39.17 & 86.17 & 37.09 & 28.69 \\
\hline dd & 10926.44 & 11650.61 & 8155.64 & 5478.14 & 6080.12 & 6963.52 & 12301.90 & 3067.18 & 8250.93 & 9433.96 & 7734.13 \\
\hline Dd & 11630.22 & 12397.61 & 8682.10 & 5833.14 & 6475.03 & 7414.33 & 13092.92 & 3266.13 & 8783.41 & 10042.71 & 8233.59 \\
\hline Ed & 1.06 & 1.06 & 1.06 & 1.06 & 1.06 & 1.06 & 1.06 & 1.06 & 1.06 & 1.06 & 1.00 \\
\hline Bd & 1.92 & 1.73 & 0.69 & 0.97 & 0.74 & 0.83 & 0.67 & 0.57 & 0.66 & 0.85 & 0.73 \\
\hline
\end{tabular}

Tabel 10. Distribusi Pergerakan Kendaraan Antar Kecamatan di Kabupaten Ketapang Tahun 2023 (lanjutan)

\begin{tabular}{|c|c|c|c|c|c|c|c|c|c|c|c|c|}
\hline 12 & 13 & 14 & 15 & 16 & 17 & 18 & 19 & 20 & oi & $\mathbf{O i}$ & Ei & $\mathbf{A i}$ \\
\hline 421.92 & 1546.95 & 837.03 & 307.35 & 157.27 & 62.42 & 63.47 & 39.31 & 17.40 & 9615.00 & 10230.13 & 1.06 & 7.34E-05 \\
\hline 70.00 & 212.25 & 114.84 & 457.20 & 233.95 & 92.85 & 94.41 & 58.47 & 25.88 & 10715.56 & 11354.25 & 1.06 & $8.43 \mathrm{E}-05$ \\
\hline 76.70 & 232.57 & 125.84 & 500.97 & 256.35 & 101.74 & 103.45 & 64.07 & 28.36 & 9082.99 & 9668.07 & 1.06 & 3.13E-05 \\
\hline 43.69 & 132.46 & 71.67 & 285.33 & 146.00 & 57.95 & 58.92 & 36.49 & 16.15 & 6966.09 & 7419.82 & 1.07 & $4.40 \mathrm{E}-05$ \\
\hline 33.78 & 102.43 & 55.43 & 220.65 & 112.91 & 44.81 & 45.56 & 28.22 & 12.49 & 6950.35 & 7419.82 & 1.07 & $3.40 \mathrm{E}-05$ \\
\hline 78.91 & 239.26 & 129.46 & 515.40 & 263.73 & 104.67 & 106.43 & 65.91 & 29.17 & 7504.85 & 7981.89 & 1.06 & 3.77E-05 \\
\hline 234.42 & 710.78 & 384.60 & 1531.09 & 783.46 & 310.94 & 316.16 & 195.81 & 86.67 & 11734.67 & 12478.38 & 1.06 & $3.02 \mathrm{E}-05$ \\
\hline 111.89 & 266.38 & 144.14 & 730.76 & 373.93 & 148.41 & 150.90 & 93.46 & 41.36 & 4861.61 & 5171.58 & 1.06 & $2.46 \mathrm{E}-05$ \\
\hline 216.91 & 795.28 & 430.32 & 1093.36 & 559.47 & 222.05 & 225.77 & 139.83 & 61.89 & 9090.26 & 9668.07 & 1.06 & $2.78 \mathrm{E}-05$ \\
\hline 458.05 & 1679.44 & 908.72 & 333.67 & 170.74 & 67.76 & 68.90 & 42.67 & 18.89 & 8549.31 & 9106.01 & 1.07 & 3.07E-05 \\
\hline 480.74 & 1762.61 & 953.73 & 252.89 & 129.74 & 51.49 & 52.36 & 32.43 & 14.35 & 6962.97 & 7419.82 & 1.07 & $2.60 \mathrm{E}-05$ \\
\hline 0.00 & 2678.33 & 570.28 & 440.06 & 225.18 & 89.37 & 90.87 & 56.28 & 24.91 & 6430.02 & 6857.76 & 1.07 & 3.74E-05 \\
\hline
\end{tabular}


Juniardi dan Azwansyah. "Pengembangan infrastruktur jalan di Kabupaten Ketapang"

\begin{tabular}{|c|c|c|c|c|c|c|c|c|c|c|c|c|}
\hline 1826.41 & 0.00 & 1425.85 & 463.94 & 237.40 & 94.22 & 95.80 & 59.33 & 26.26 & 9621.26 & 10230.13 & 1.06 & 4.07E-05 \\
\hline 572.94 & 2100.67 & 0.00 & 247.95 & 127.21 & 50.49 & 51.33 & 31.79 & 14.07 & 7494.84 & 7981.89 & 1.06 & $2.61 \mathrm{E}-0$ \\
\hline 481.33 & 744.13 & 269.95 & 0.00 & 1608.64 & 638.44 & 649.16 & 402.05 & 177.95 & 10675.15 & 11354.25 & 1.06 & $3.18 \mathrm{E}-05$ \\
\hline 267.54 & 413.61 & 150.43 & 1747.38 & 0.00 & 1318.63 & 1340.76 & 830.39 & 367.53 & 9606.91 & 10230.13 & 1.06 & $3.79 \mathrm{E}-05$ \\
\hline 136.22 & 210.60 & 76.60 & 889.72 & 1691.72 & 0.00 & 682.69 & 422.81 & 187.14 & 5911.93 & 6295.70 & 1.06 & $6.22 \mathrm{E}-05$ \\
\hline 116.99 & 180.87 & 65.78 & 764.10 & 1452.86 & 576.62 & 0.00 & 2427.33 & 1074.35 & 8045.38 & 8543.95 & 1.06 & $5.12 \mathrm{E}-05$ \\
\hline 73.22 & 113.21 & 41.17 & 478.26 & 909.35 & 360.91 & 2453.06 & 0.00 & 2176.23 & 7473.21 & 7981.89 & 1.07 & $6.18 \mathrm{E}-0$ \\
\hline 42.28 & 65.36 & 23.77 & 276.12 & 525.01 & 208.37 & 1416.25 & 2838.71 & 0.00 & 5896.88 & 6295.70 & 1.07 & 8.27E-05 \\
\hline 5743.94 & 14187.19 & 6779.61 & 11536.21 & 9964.93 & 4602.12 & 8066.24 & 7865.37 & 4401.06 & 163189.25 & & & \\
\hline 6115.49 & 15096.15 & 7216.92 & 12277.40 & 10602.84 & 4899.68 & 8581.34 & 8365.10 & 4683.14 & & 173689.24 & & \\
\hline 1.06 & 1.06 & 1.06 & 1.06 & 1.06 & 1.06 & 1.06 & 1.06 & 1.06 & & & & \\
\hline 1.10 & 1.07 & 0.76 & 0.71 & 0.81 & 1.38 & 1.04 & 1.19 & 1.73 & & & & \\
\hline
\end{tabular}

(Sumber : Analisis data, 2013)

Hasil analisis distribusi pergerakan kendaraan antar kecamatan di Kabupaten Ketapang seperti pada Tabel 10, selanjutnya digambarkan dalam bentuk garis keinginan (desireline) seperti dapat dilihat pada Gambar 1.

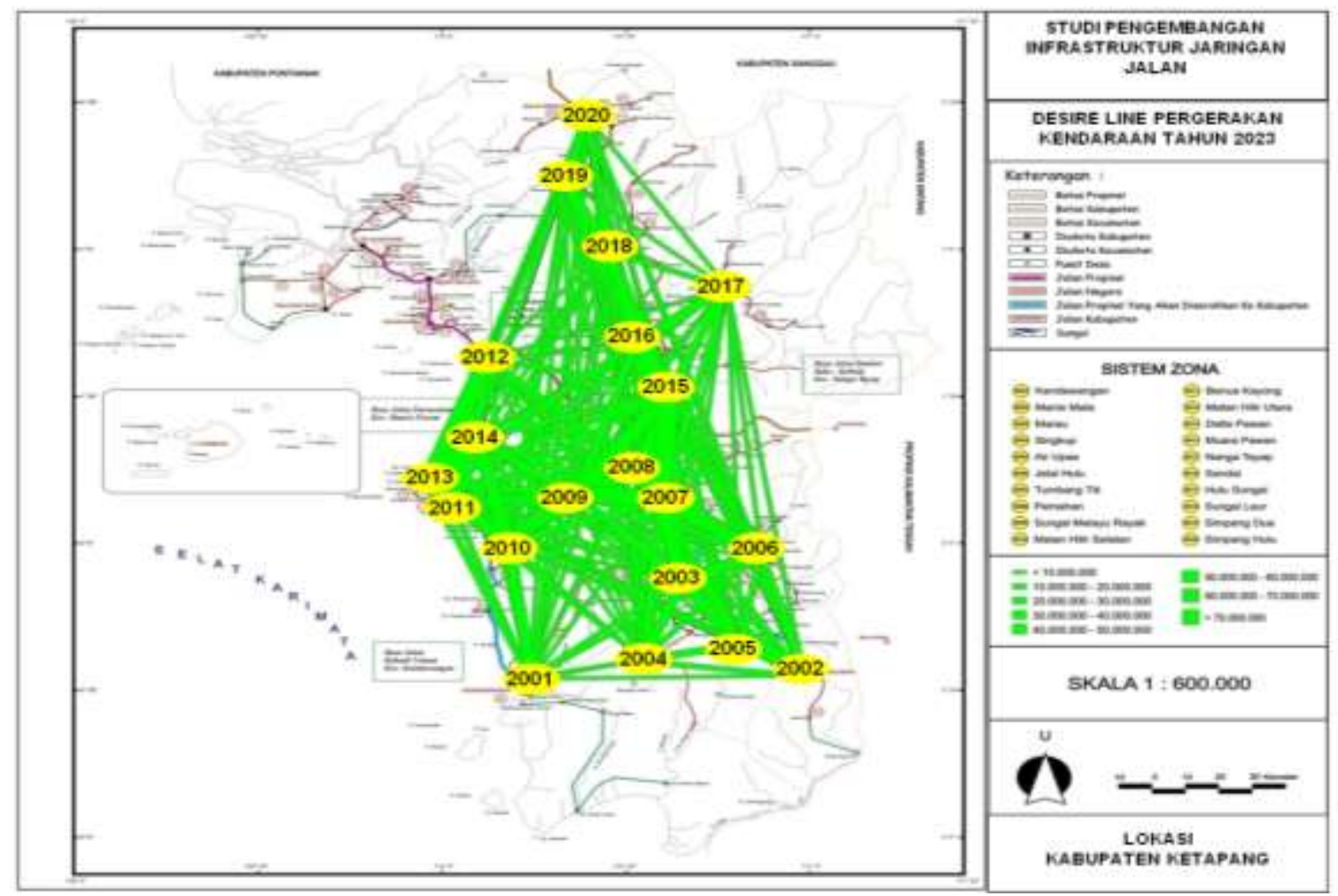

Gambar 1. Desireline Pergerakan Kendaraan di Kabupaten Ketapang Tahun 2023

(Sumber : Analisis data, 2013)

Gambar 1 memperlihatkan distribusi pergerakan kendaraan antar kecamatan di Kabupaten Ketapang pada tahun 2023. pada gambar tersebut dapat dipahami ada beberapa pergerakan antar kecamatan yang relatif tinggi dan beberapa pergerakan kendaraan antar kecamatan yang relatif rendah yang digambarkan dengan ketebalan garis pergerakan. Hubungan antar daerah yang memiliki potensi pergerakan relatif tinggi tentunya akan menjadi pertimbangan dalam

Tabel 11. Rekapitulasi analisis Kinerja Jalan Tahun 2023 pengembangan jaringan jalan.

Data distribusi pergerakan kendaraan seperti pada Tabel 10 menjadi data input dalam proses analisis pembebanan lalu lintas. Proses pembebanan lalu lintas akan menghasilkan data volume lalu lintas yang melalui jaringan jalan yang ada, selanjutnya dilakukan analisis derajat kejenuhan untuk tahun 2023 yang dapat dilihat pada Tabel 11. 
Juniardi dan Azwansyah. "Pengembangan infrastruktur jalan di Kabupaten Ketapang"

\begin{tabular}{|c|c|c|c|c|c|}
\hline \multirow{2}{*}{ No } & \multirow{2}{*}{ Nama Ruas } & \multirow{2}{*}{$\mathbf{L}$} & \multicolumn{3}{|c|}{ Tahun 2023} \\
\hline & & & $\mathbf{Q}$ & C & DS \\
\hline 1 & SIDUK - KETAPANG & 6 & 516 & 2736 & 0.19 \\
\hline 2 & KETAPANG - PESAGUAN & 6 & 1596 & 2736 & 0.58 \\
\hline 3 & PESAGUAN - KELAPA ENAM BATANG & 5 & 141 & 2075 & 0.07 \\
\hline 4 & KELAPA ENAM BATANG - KENDAWANGAN & 6 & 141 & 2736 & 0.05 \\
\hline 5 & PESAGUAN -PENGANCING & 6 & 1367 & 2736 & 0.50 \\
\hline 6 & PENGANCING - TUMBANG TITI & 6 & 1372 & 2736 & 0.50 \\
\hline 7 & TUMBANG TITI - PEMBIBINGAN & 6 & 1839 & 2736 & 0.67 \\
\hline 8 & PEMBIBINGAN - BUKIT MAS & 6 & 1839 & 2736 & 0.67 \\
\hline 9 & BUKIT MAS - BATAS KALTENG & 6 & 171 & 2648 & 0.06 \\
\hline 10 & BUKIT MAS - BETENUNG & 6 & 844 & 2648 & 0.32 \\
\hline 11 & BETENUNG - NANGA TAYAP & 6 & 844 & 2736 & 0.31 \\
\hline 12 & NANGA TAYAP - BATAS KALTENG & 6 & 166 & 2736 & 0.06 \\
\hline 13 & NANGA TAYAP - SANDAI & 6 & 417 & 2736 & 0.15 \\
\hline 14 & SANDAI - KEBUWAI & 6 & 29 & 2736 & 0.01 \\
\hline 15 & TUMBANG TITI - TANJUNG & 6 & 1666 & 2736 & 0.61 \\
\hline 16 & TANJUNG - RIAM & 6 & 997 & 2736 & 0.36 \\
\hline 17 & RIAM - SENGKUANG & 5 & 926 & 2075 & 0.45 \\
\hline 18 & SENGKUANG - KEMUNING & 5 & 38 & 2075 & 0.02 \\
\hline 19 & TANJUNG - SUKA RAJA & 6 & 869 & 2648 & 0.33 \\
\hline 20 & SUKA RAJA - SINGKUP & 5 & 869 & 2075 & 0.42 \\
\hline 21 & SINGKUP - KETIKAL & 5 & 63 & 2075 & 0.03 \\
\hline 22 & SINGKUP - SENGKUANG & 5 & 42 & 2075 & 0.02 \\
\hline 24 & JUDIK - MANIS MATA & 6 & 202 & 2075 & 0.10 \\
\hline
\end{tabular}

Keterangan:

$\mathrm{Q}=$ voliume lalu lintas (smp/jam)

$\mathrm{C}=$ kapasitas jalan (smp/jam)

$\mathrm{DS}=\mathrm{Q} / \mathrm{C}=$ derajat kejenuhan jalan .

(sumber : Analisis data, 2013)

Berdasarkan Tabel 11 bahwa nilai derajat kejenuhan (DS) pada jalan-jalan yang ditinjau pada tahun 2023 berkisar 0,02 sampai dengan 0,67. Berdasarkan penjelasan sebelumnya pada bagian ladasan teori di atas, bahwa derajat kejenuhan (DS) disyaratkan tidak melebihi 0,8 . Berdasarkan nilai DS ini diketahui bahwa kapasitas jalan yang ada masih mampu mengalirkan lalu lintas sampai tahun 2023.

Dalam pengembangan infrastruktur jaringan jalan selain parameter kinerja jalan (derajat kejenuhan), juga yang harus diperhatian adalah hubungan jaringan jalan dengan pusat kegiatan sebagai wilayah strategis. Pusat-pusat kegiatan di Kabupaten Ketapang dapat dilihat pada bagian 2.4 .

Dengan pertimbangan hal tersebut, maka pengembangan infrastruktur jaringan jalan adalah sebagai berikut :

- Arah pengembangan sistem jaringan lalu lintas dan angkutan jalan di 
Kabupaten Ketapang adalah sebagai berikut :

a. Jaringan jalan arteri primer.

Pengembangan jaringan jalan ini merupakan akses menuju wilayah Kalimantan Tengah melalui poros tengah. Jalur poros tengah ini meliputi wilayah Pontianak Sanggau (Tayan) - Ketapang batas Kalimantan Tengah.

Pengembangan jaringan jalan tersebut meliputi:

- Ruas Jalan Bts. Kabupaten Sanggau - Bts. Balai Berkuak;

- Ruas Jalan Bts. Balai Berkuak Aur Kuning;

- Ruas Jalan Aur Kuning - Sandai;

- Ruas Jalan Sandai - Nanga Tayap; dan

- Ruas Jalan Nanga Tayap - Bts. Provinsi Kalimantan Tengah (ke PKN Palangkaraya);

b. Jaringan jalan kolektor primer K2 atau strategis nasional rencana yang dipersiapkan untuk ditingkatkan fungsinya menjadi jalan arteri primer yang menghubungkan PKN (Kota Pontianak dengan PKW (Kota Ketapang) melalui Kabupaten Kayong Utara (Penyeberangan Ferry Telok Batang), meliputi:

- Ruas jalan Nanga Tayap Sungai Kelik;

- Ruas jalan Sungai Kelik - Bts. Kabupaten Kayong Utara (ke Siduk);

c. Jaringan jalan kolektor primer K2, yang menghubungkan PKN (Kota Pontianak) dengan PKW (Kota Ketapang) melalui Kabupaten Sekadau meliputi:

- Ruas jalan Baram - Tanjung Maju - Sp. Tanjung Rambut -
Setabu - Mungguk Meranang Merabu - Bts. Kabupaten Sekadau;

d. Jaringan jalan kolektor primer K2, yang menghubungkan PKN (Kota Palangkaraya, Kalimantan Tengah) dengan PKW (Kota Ketapang) meliputi:

- Ruas jalan Simpang Dua Selantak - Merangin - Perawas; Ruas jalan Nanga Tayap Tumbang Titi - Tanjung - Marau;

- Ruas jalan Marau - Sedawak Sengkuang - Air Upas - Asam Besar - Beriam (Manis Mata) Paku Juang - Sp. Danau Buntar - Sp. Jambi - Sukaramai (Bts. Kalimantan Tengah, ke Sukamara);

- Ruas jalan Batas Kota Ketapang (PKW) - Pesaguan; dan

- Ruas jalan Pesaguan Kendawangan;

e. Jaringan jalan kolektor primer K3 yang menghubungkan antar antara PKW dan PKL meliputi :

Akses PKW (Kota Ketapang) dengan PKL (Manis Mata) yaitu : Ruas jalan Sungai Gantang Sp. Kelampai - Air Putih Pinang - Sp. Teluk Bayur Teluk Batu - Belaban - Sp. Jemayas (Marau);

- Akses PKW (Kota Ketapang) dengan PKL (Tumbang Titi) yaitu : Ruas jalan Batu Tajam II (Tumbang Titi) - Sungai Melayu - Pelang.

- Rencana pengembangan jaringan jalan tersebut secara jelasnya dapat dilihat pada Gambar 2. 


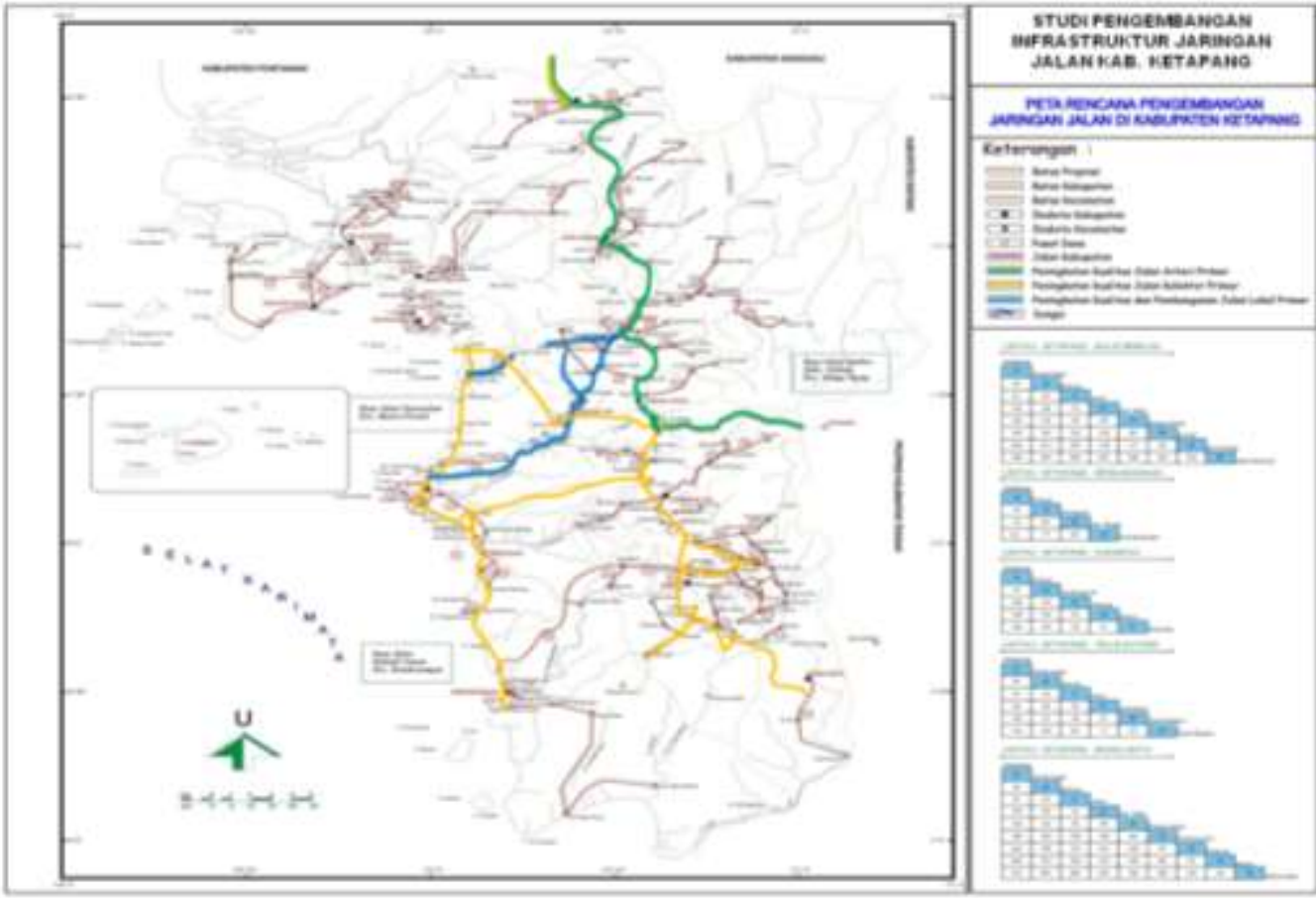

Gambar 2. Peta Pengembangan Jaringan Jalan Kabupaten Ketapang

(Sumber : Analisis data, 2013)

\section{Kesimpulan}

Dari hasil studi dan analisis terhadap pengembangan jaringan jalan Kabupaten Ketapang ini, maka diperoleh kesimpulan sebagai berikut :

- Model bangkitan pergerakan kendaraan dipengaruhi oleh jumlah sarana kesehatan $\left(X_{3}\right)$, sedangkan model tarikan pergerakan dipengaruhi oleh jumlah penduduk $\left(\mathrm{X}_{1}\right)$ dan jumlah sarana kesehatan $\left(X_{3}\right)$,

- Kinerja jalan yang ada di Kabupaten Ketapang sampai tahun 2023 masih memadai dengan derajat kejenuhan di berkisar 0,02 sampai dengan 0,07,

- Pengembangan jalan arteri primer untuk mendukung akses menuju wilayah Kalimantan Tengah melalui jalan poros tengah yang melewati Kabupaten Ketapang meliputi :

- Ruas Jalan Bts. Kabupaten Sanggau - Bts. Balai Berkuak;

- Ruas Jalan Bts. Balai Berkuak - Aur Kuning;

- Ruas Jalan Aur Kuning - Sandai;

- Ruas Jalan Sandai - Nanga Tayap; dan

- Ruas Jalan Nanga Tayap - Bts. Provinsi Kalimantan Tengah (ke PKN Palangkaraya);

- Jaringan jalan kolektor primer K2 atau strategis nasional rencana yang dipersiapkan untuk ditingkatkan fungsinya menjadi jalan arteri primer yang menghubungkan PKN (Kota Pontianak dengan PKW (Kota Ketapang) melalui Kabupaten Kayong Utara (Penyeberangan Ferry Telok Batang), meliputi:

- Ruas jalan Nanga Tayap - Sungai Kelik;

- Ruas jalan Sungai Kelik - Bts. Kabupaten Kayong Utara (ke Siduk);

- Jaringan jalan kolektor primer K2, yang menghubungkan PKN (Kota Pontianak) dengan PKW (Kota Ketapang) melalui Kabupaten Sekadau meliputi:

- Ruas jalan Baram - Tanjung Maju Sp. Tanjung Rambut - Setabu Mungguk Meranang - Merabu Bts. Kabupaten Sekadau;

- Jaringan jalan kolektor primer K2, yang menghubungkan PKN (Kota Palangkaraya, Kalimantan Tengah) dengan PKW (Kota Ketapang) meliputi:

- Ruas jalan Simpang Dua - Selantak - Merangin - Perawas;

- Ruas jalan Nanga Tayap Tumbang Titi - Tanjung - Marau;

- Ruas jalan Marau - Sedawak Sengkuang - Air Upas - Asam Besar - Beriam (Manis Mata) Paku Juang - Sp. Danau Buntar Sp. Jambi - Sukaramai (Bts. Kalimantan Tengah, ke Sukamara); 
- Ruas jalan Batas Kota Ketapang yang terlibat yang tidak dapat penulis (PKW) - Pesaguan; dan

- Ruas jalan Pesaguan Kendawangan;

- Jaringan jalan kolektor primer K3 yang menghubungkan antar antara PKW dan PKL meliputi :

- Akses PKW (Kota Ketapang) dengan PKL (Manis Mata) yaitu :

Ruas jalan Sungai Gantang - Sp. Kelampai - Air Putih - Pinang - Sp. Teluk Bayur - Teluk Batu - Belaban Sp. Jemayas (Marau);

- Akses PKW (Kota Ketapang) dengan PKL (Tumbang Titi) yaitu : Ruas jalan Batu Tajam II (Tumbang Titi) Sungai Melayu - Pelang.

\section{Ucapan Terima kasih}

Penulis mengucapkan terima kasih yang sebesar-besarnya kepada pihakpihak yang telah membantu dalam setiap atau sebagian tahapan dari studi ini baik langsung maupun tidak langsung. Ucapan terima kasih terutama penulis sampaikan kepada pimpinan dan seluruh staf Dinas Perhubungan Komunikasi dan Informatika Kabupaten Ketapang serta pihak-pihak uraikan satu persatu.

\section{Referensi}

BPS Kabupaten Ketapang. 2012. Kabupaten Ketapang Dalam Angka. BPS Kabupaten Ketapang. Ketapang.

Dirjen Bina Marga. 1997. Manual Kapasitas Jalan Indoensia. Jakarta.

Lubis, Muhammad E. 2012. Penetapan Model Bangkitan Pergerakan Untuk Beberapa Tipe Perumahan di Kota Pematangsiantar, Media Teknik Sipil, Volume 10, Nomor 1, Februari 2012: 27 - 34. Fakultas Teknik Universitas Muhammadiyah Malang. Malang.

Raperda RTRW Kabupaten Ketapang 2013 - 2033. Ketapang

Tamin, Ofyar Z. 2008. Perencanaan, Pemodelan, dan Rekayasa Transportasi : Teori, Contoh Soal, dan Aplikasi. Penerbit ITB. Bandung. ---. 2009. Undang-Undang Republik Indonesia Nomor 22 Tahun Tentang Lalu Lintas dan Angkutan Jalan. Sekretariat Negara RI. Jakarta 